\title{
INDUSTRIAL SOLID \\ WASTE MANAGEMENT IN \\ BRAZIL AND THE BASEL \\ CONVENTION
}

GESTÃO DE RESÍDUOS SÓLIDOS INDUSTRIAIS NO BRASIL E A CONVENÇÃO DE BASEL

GESTIÓN DE RESIDUOS SÓLIDOS INDUSTRIALES EN BRASIL Y LA CONVENCIÓN DE

BASILEA

Luciana Ziglio ${ }^{1}$

ABSTRACT: The Basel Convention on the Control of Transboundary Movement of Hazardous Wastes and their Disposal - Basel Convention - was adopted internationally in 1989, and in Brazil in 1993. The Basel Convention seeks to control international movement of hazardous wastes between countries. Certain types of industrial waste are considered hazardous, therefore the Basel Convention applies to their movement. Brazil, as a signatory country to the Basel Convention, has industrial waste management and performs transboundary movements when possible. This paper presents the Brazilian legislation for the internationalization of the Convention, and the scenario of industrial waste management in Brazil. For this purpose, it gives an overview of the Basel Convention guidelines. The methodology consists of secondary data analyses, and in

1 PHD in Human Geography and Environment, University of São Paulo, São Paulo, Brazil, e mail Iziglio@usp.br. 
the final consideration, it is proposed that the Basel Convention is strengthened by the Brazilian laws and the consolidation of industrial waste management in Brazil.

KEYWORDS: Management. Industrial Waste. Brazil. Basel Convention.

RESUMO: A Convenção de Basileia sobre o Controle de Movimentos Transfronteiriços de Resíduos Sólidos e Disposição Final - CB, adotada internacionalmente em 1989 e no Brasil em 1993, estabelece o controle internacional de movimentos de resíduos perigosos entre países. Certos resíduos industriais são considerados perigosos e, portanto, utilizam a Convenção para movimentação. $O$ Brasil, signatário da $C B$, realiza gestão de seus resíduos industriais e, quando necessário, pratica a movimentação transfronteiriça. Este artigo busca apresentar a legislação brasileira para a internalização da Convenção e o cenário de gestão dos resíduos sólidos industriais no Brasil e, para alcançar este objetivo, os princípios norteadores da CB serão mencionados. A metodologia utilizada compreende a análise de dados secundários e, por considerações finais, temse o fortalecimento da CB pelas leis brasileiras e a consolidação da gestão dos resíduos industriais no Brasil.

PALAVRAS-CHAVE: Gestão. Resíduos Industriais. Convenção de Basiléia. Brasil.

RESUMEN: La Convención de Basilea sobre el Control de Movimientos Transfronterizos de Residuos Sólidos y Disposición Final - CB, adoptada internacionalmente en 1989 y en Brasil en 1993, establece el control internacional de movimientos de residuos peligrosos entre países. Ciertos residuos industriales son considerados peligrosos y por lo tanto utilizan la Convención para su movimentación. Brasil, signatario de la $C B$, realiza la gestión de sus residuos industriales, y cuando es necesario practica la movimentación transfronteriza. Este artículo quiere presentar la legislación brasileña para la internalización de la Convención y el escenario de la gestión de los residuos 
sólidos industriales en Brasil, y para lograr este objetivo serán mencionados los principios norteadores de laCB. La metodología utilizada comprende el análisis de datos secundarios, y como consideraciones finales está el fortalecimiento de la CB por las leyes brasileñas y la consolidación de la gestión de los residuos industriales en Brasil.

PALABRAS CLAVE: Gestión. Residuos Industriales. Convención de Basilea. Brasil.

\section{INTRODUCTION}

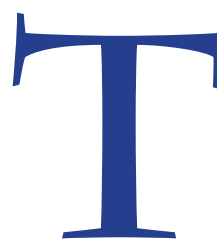
The Basel Convention on the Control of Transboundary Movement of Hazardous Wastes and their Disposal was adopted internationally during the 1990s, as a worldwide response to the need to control the disposal of waste movements between countries. This paper invites the reader to become acquainted with Brazil's position in relation to this document, and the mechanisms by which it is incorporated into the Brazilian legislation. It gives an overview of the national industrial solid waste management, bearing in mind that such practices are comparable to those applied in others countries with similar realities. The text demonstrates the objectives and methodology applied, followed by the guiding principles of the Basel Convention. It gives an introduction to the Brazilian industrial waste management scenario and its legislation, and to conclude, it exemplifies some of the lessons learned from the Brazilian experience regarding industrial waste management.

This objective of this paper is to present the Brazilian industrial waste management scenario and the laws that allowed the internalization of the Basel Convention in the Brazilian territory. However, it is important to place the main characteristics of the Basel Convention in context, in order to fulfil the objective of this paper. The methodology used in this paper is analysis of secondary data.

Secondary data was obtained through electronic research sources that express the position of the Basel Convention signatory countries, as well as that of Brazilian 
environmental bodies that deal with industrial solid waste management. The Brazilian legislation detailed in this article includes Decrees, Laws, Resolutions and technical Norms², e.g. Decree 875/93, which promulgates the text of the Basel Convention in Brazil (<https://www.planalto.gov.br/ccivil_03/decreto/ D0875.htm>). The Environmental Crimes Law 9.605/98 reaffirms the polluter payer principle for industrial waste, (<http://www.planalto.gov.br/ccivil_03/ leis-/L9605.htm>). Decree 5.098/04 created the National Plan for prevention and immediate response to disasters involving hazardous chemical products, (<http://www.mp.sc.gov.br/legisla/indice/legfed_df.htm>). Among the available resolutions are CONAMA 023/9633, which specifies the Brazilian procedures for soliciting imported waste and CONAMA 313/02, which provides guidelines on the solid residue inventory (<http://www.mma.gov.br/conama/>). ABNT Standard ${ }^{44}$ 10,004/04 covers waste in the national territory; and ABNT 13,221/94 regulates waste movement (<www.abnt.org.br>). Finally, there is the Law on 2 Complementary law is used under the Brazilian Federal Constitution. Regulation hypotheses are included as complementary law in the Brazilian Federal Constitution (art. 59 Brazilian Federal Constitution-CF). Legislative Decree is a norm used for hypothesis within the scope of the National Congress only (art. 49 CF) and rules regarding its procedures are included in its internal rules. A resolution is a norm used only within the scope of the House of Deputies, Senate House or National Congress (art. 51 and 52 CF). Norms are complementary instruments for decrees, laws, treaties and international conventions (art. 100 Tributary National Code - CTN). However, norms in this paper refers to procedures that allow the production, commercialization, and use of goods and services in a competitive way and on a national and international scale, and which establish environmental protection but are not necessarily read as standards according to article 100 of the CTN. CÓDIGO TRIBUTÁRIO NACIONAL. Fontes do direito tributário. Brasília: 1988. Online [http://www. webjur.com.br/doutrina/Direito_Tribut_rio/Fontes_do_Direito_Tribut_rio.htm]. Accessed on: January 30, 2013.

$3 \quad{ }^{3}$ The National Council for the Environment (CONAMA), the consultation and debating agency of the National System for the Environment (SISNAMA), was created by Law 6.938/81, which governs the National Environmental Policy. The CONAMA has a Plenary council, CIPAM, Consultation Groups, Technical Chambers and Workgroups. The Council is presided over by the Minister for the Environment, and the Executive Secretariat is presided over by the Exectuvie Secretary of the Ministry of the Environment. The Council is a collegiate body that represents five sectors, namely, federal, state and municipal agencies, private corporations and the general public. Its duty is to establish, upon proposal from the Brazilian Institute for the Environment and Natural Renewable Resources (IBAMA), from the other agencies within SISNAMA and from CONAMA Advisors, regulations and criteria for licensing polluting, or potentially polluting activities, to be conceded by the Union, States, Federal District and Municipalities, and overseen by the aforementioned Institute. In: CONSELHO NACIONAL DO MEIO AMBIENTE. O que é o CONAMA. Brasília: 2012. Online [http://www. mma.gov.br/port/conama/estr.cfm]. Accessed on: January 30, 2012.

$4 \quad{ }^{4}$ Body responsable for the technical standards in the country. It provides the necessary basis for Brazilian technological development. It is a non-profit-making private society, recognized as the National Standardization Forum by resolution 07 issued by CONMETRO on 24 August, 1992. 
Waste Management in Brazil, 12,305/10 (<http://www.planalto.gov.br/ccivil_03/_ ato2007-2010/2010/lei/l12305.htm >) which regulates hazardous waste, in its articles 37, 38, 40 and 41.

\section{THE BASEL CONVENTION ON THE CONTROL OF TRANSBOUNDARY MOVEMENT OF HAZARDOUS WASTES AND THEIR DISPOSAL (BASEL CONVENTION)}

Situations of risk have escalated in contemporary society, and various authors have described this as a "risk society" ${ }^{55}$ Although exposure to risk existed in the past, ${ }^{6}$ today's industrial and consumer society generates greater risks, and the relationship between the population and risk has become naturalized ${ }^{76}$

There is no doubt that industrial waste creates risks for humans and other life forms. The situation requires regulation of movements of wastes between countries 87981091110 . Contemporary society, and the massive waste production of its industries, have led to unacceptable levels of refuse on the planet. As a result, proper management is required, and the Basel Convention is a step in this direction in that it regulates the destination of waste, and where necessary, its movement and transportation ${ }^{121} 1$.

During the 1980s, environmental laws in industrialized countries restricted the disposal of hazardous waste to within their own territories. Consequently, movements of such residues to poor countries, which still had no legislation in the $5 \quad{ }^{5}$ BECK, Ulrich. La sociedad del riesgo: hacia una nueva modernidad. Barcelona: Paidós, 2006.

$7 \quad{ }^{6}$ NOVEMBER, Valerie. Les Territoires du risque: le risque comme objet de refléxion géographique. Berna: Lang, 2002

$8{ }^{7}$ EL-FADELA, Mutasem. Industrial-waste management in developing countries: The case of Lebanon. Journal of Environmental Management. 2002. Online [http://dx.doi. org/10.1006/jema.2000.0413]. Acesso em: 3101.2013.

$9{ }^{8}$ LEFF, Enrique. Saber Ambiental: sustentabilidade, racionalidade, complexidade e poder. Rio de Janeiro: Vozes, 2001.

$10{ }^{9}$ CALVO GARCÍA-TORNEL, Francisco. Sociedades y territorios en riesgo.Espanha: Ediciones del Serbal, 2001.

$11{ }^{10}$ RIBEIRO, Wagner. A ordem ambiental internacional. São Paulo: Contexto, 2001(a).

$12{ }^{11}$ ELLIOTT, Lorraine. The Global Politics and Environment. United States: Macmillan 1998 
area, became frequent ${ }^{1312}$. These movements generated pressure on governments and environmentalists to ban this trade, since the concern for its effects on human and environmental health in the receiving population were nonexistent. One of the results was regulation through an International Treaty (Martínez-Alier, 2007; Meyers and Anbarci, 2006). Another important result was the expression "not in my backyard" or Nimbi Principle (Barbalace, 2001).

In 1989, the year in which the Basel Convention was formed, 40 million tons of waste were transported as scrap and commercialized within the OECD Organization for Economic Cooperation and Development ${ }^{1413}$. In that same year, the final cost of disposing of one ton of industrial waste was between US\$100 and US\$2000 in OCDE countries (United States, Canada, Western Europe, Japan), and between US\$ 2.50 and US\$ 50 in Africa ${ }^{1514}$. It is estimated that in 1990, 400 million metric tons of hazardous waste were generated worldwide. Over ninety percent of this waste originated in countries belonging to the OECD ${ }^{1615}$.

Initial efforts in the search for this instrument began in 1981, under the United Nations Environmental Programme - UNEP, in a meeting with legislation specialists in Montevideo, Uruguay. In 1989, at the Plenipotentiary Conference, a world reference document was born, known as the Basel Convention. This instrument was the result of an international effort to regulate movements of environmentally hazardous wastes. It has 179 parties and 53 signatories $^{1716}$ (Tsimplis, 2004; Kamuk and Hansen, 2007).

The commitments of the Basel Convention are: the need for prior consent, in writing, of the importing country; the adoption of measures to minimize

$13{ }^{12}$ KUO-SHUH, Fan, Tien Chin Chang, Shih-Piao Ni, Ching-Hwa Lee. Transboundary hazardous waste management. Part I: waste management policy of importing countries. Waste Management \& Research. 2005, 23, 505 - 513.

$14{ }^{13}$ OECD, Waste Management Policy Group:Working Paper, number 3, for the 37th. Meeting - March, 1993. < http://ban.org/library/lipman.html\#fn2 > Accessed on March 2, 2013.

$15{ }^{14}$ UNITED NATIONS ENVIRONMENT PROGRAM. UNEP. Global trends in generation and transboundary movements of hazardous wastes and other wastes. Switzerland: UNEP, 2002.

$16{ }^{15}$ Kummer,K. International Management of Hazardous Wastes, Clarendon Press Oxford 1995, p. 10.

$17{ }^{16}$ BASEL CONVENTION. Parties to the Basel Convention. 1989. Online [http://www. basel.int/Countries/StatusofRatifications/PartiesSignatories/tabid/1290/Default.aspx] 
waste generation that take into consideration social technological and economic aspects; environmental health management of hazardous waste and its disposal (Mancini and Kagohara, 2007); internal measures to support the implementation of the convention; the possibility of moving wastes between member States and non-member States only under a cooperation agreement (Sanchez, 2006); the requirement that transboundary transport complies with international norms and standards on packaging, labelling and transport; and permission for transboundary movement of hazardous waste, provided the waste is needed for recycling and recovery industries within the importer's country ${ }^{1817}$ (Fusel, et. al, 2001).

To endorse all its recommendations, the Basel Convention has an amendment called the Basel Protocol on liability and compensation for damage resulting from transboundary movements of hazardous waste (also referred to as the "Liability Protocol"). This is prescribed in its Article 12, which requires twenty ratifications for its validation.

\section{This Protocol has 13 signatory countries ${ }^{1918}$ (Krueger, 1998; Tsimplis, 2004).}

The Basel Convention is based on national management plans, and aims to achieve the above-mentioned guidelines by 2010. The proposal and strategies were elaborated during the ninth meeting of the Conference of the Parties (COP9). Management plans for 2010-2020 were discussed at the $9^{\text {th }}$ conference, which took place in Indonesia. These conferences aimed to reaffirm the fundamental principles of the Basel Convention, and to initiate the preparation of national plans for waste management in all the signatory countries by the next decade.

The plans were sent to the Secretariat of the Basel Convention, so that an international waste management plan could be drawn up, respecting national interests. National plans are important instruments for restricting illegal traffic of waste, which is the ultimate goal of the Basel Convention. These plans establish the concept of waste in each country, the rules on circulation, labelling procedures, and other aspects (Gerber, et. al, 2009).

$18{ }^{17}$ The Basel Convention, articles 4, 5, 6, 10, 13, and 20. In: BASEL CONVENTION. Convenção de Basiléia sobre o controle dos movimentos transfronteiriços de resíduos perigosos e seu depósito. 1989. Online [www.basel.int]. Accessed on: 01/25/2012.

$19{ }^{18}$ For more information about the protocol in: BASEL CONVENTION. Basel Protocol on Liability and Compensation for Damage Resulting from transboundary movements of hazardous waste.1999. Online <www.basel.int/ratif/protocol.htm> Accessed on: $01 / 27 / 2013$. 
Two decades later, the Basel Convention has made some progress, but there are also some deadlocks. One successful result is that the transport of 400 million tons of hazardous wastes generated across the globe each year now has to be declared to the Secretariat of the Basel Convention (Agamathu, 2005; Taggart, 2006). However, conflicts and setbacks are also occurring, with countries refusing to report transport, and some countries that have not yet signed up to the Basel Convention ${ }^{2019}$.

When the Brazilian government signed up to the Basel Convention in 1993, it became part of an instrument that regulates waste movement based on the principle of prior consent. This instrument aims to stop the illicit transport of wastes, and step up international cooperation for adequate governance, as stated in the first article, paragraph one of Decree 875/93, which promulgates the Brazil Convention (Kempel, 2004) 2120.

The table below shows the waste movements at the time Brazil adopted the Basel Convention.

Table 1 -Waste Trading Countries: 1993-1997 (tons)

\begin{tabular}{|l|l|l|l|l|}
\hline Position & Country & Exportation & Importation & Balance \\
\hline 1 & Germany & $6,973,329$ & $2,945,130$ & $4,028,199$ \\
\hline 2 & USA & $3,814,917$ & $1,754,855$ & $2,060,062$ \\
\hline 3 & Netherlands & $2,457,216$ & $1,913,256$ & 543,960 \\
\hline 4 & Belgium & $2,020,086$ & $3,249,027$ & $-1,228,941$ \\
\hline 5 & Canadian & $1,600,116$ & $3,060,668$ & $-1,460,552$ \\
\hline 6 & Switzerland & $1,579,720$ & 366,913 & $1,212,807$ \\
\hline
\end{tabular}

$20{ }^{19}$ For further information on Toxic Waste Dumping in Ivory Coast, see : UNITARIAN UNIVERSITY SERVICE COMMITTEE. Côte d'Ivoire Toxic Waste Dumping. 2007. [http://www. uusc.org/blog/2007/02/cte-divoire-toxic-waste-dumping.html]. Accessed on: January 27, 2013. And Brazil has recently received waste from Spain. See: MÁFIA DO LIXO. Brasil na rota do tráfico internacional recebe lixo da Espanha. São Paulo: 2011. [http://www. mafiadolixo.com/2011/09/brasil-na-rota-do-trafico-internacional-recebe-conteineres-carregados-com-lixo-da-espanha/]. Accessed on January 27, 2012.

$21{ }^{20}$ Brazilian Decree the Basel Convention. In: DECRETO 875/93. Promulga o texto da Convenção sobre o Controle de Movimentos Transfronteiriços de Resíduos Perigosos e seu Depósito. Brazil: 1993. [https://www.planalto.gov.br/ccivil_03/decreto/D0875. htm]. Accessed on: January 27, 2013. 


\begin{tabular}{|l|l|l|l|l|}
\hline 7 & France & 919,683 & $3,283,962$ & $-2,364,279$ \\
\hline 8 & Russia & 876,120 & $2,455,799$ & $-1,569,679$ \\
\hline 9 & Ukraine & 737,544 & 13,390 & 724,154 \\
\hline 10 & Republic of Korea & 570,756 & 27,807 & 524,563 \\
\hline Total & & $21,549,487$ & $19,070,807$ & $2,470,294$ \\
\hline
\end{tabular}

Source: UNEP, 2002.

The table shows that trade between the countries before the Basel Convention was stronger and required regulation. Germany, the USA, and the Republic of Korea, for example, exported their waste thus Russia, France, and Canada received it. In this scenario, the Basel Convention is an important instrument for regulating movements of hazardous material between countries. When combined with national laws, it minimizes the impacts generated by final disposal of industrial waste, and prevents illegal trade in waste.

Below, a scenario is presented for industrial solid waste management, together with its regulatory legislation. The Environmental legislation, in Brazil, is an opportunity to promote environmental justice and allow trade between countries when the material is possibly used like raw material not being a waste (Yoshida and Terazono, 2010; Papu-Zamxakaa, 2010; Veiga, 2007; Acselrad, 2004).

\section{MANAGEMENT AND LEGISLATION OF INDUSTRIAL SOLID WASTE IN BRAZIL}

Industrial waste management in Brazil is partial. This is due to several reasons, including the lack of knowledge of specific waste disposal techniques and utilities, or the lack of attention to production processes (Yunchang et al., 2004; Kuo-shuh et al., 2005).

Industrial waste in Brazil is handled by third-party companies, which are responsible for the final disposal of the waste. In Brazil, there is no enterprise 
culture of industrial solid waste management, and little attention is given to treatment logistics and the final disposal of waste.

One consequence of the lack of waste management in industries is the lack of sites for disposal of solid industrial waste in Brazil (Mancini and Kagohara, 2007). This scenario began to change in the last decade, when Brazilian environmental bodies started to play a more active role with the industrial sector ${ }^{2221}$, asking Brazilian entrepreneurs to provide statistics on their practices in the generation and treatment of waste ${ }^{2322}$.

This concerted effort led to an increase in the amount of official information available on industrial waste management in the country. Official reports like the National Sanitation Survey (PNSB, 2000) and the Sustainable Development Indicators (IDS, 2004) are included in databases on industrial waste. But, even Brazil has preliminary diagnostics of final disposal and treatment for industrial solid waste. The PNSB presents information about waste management control for only 674 municipalities out of a total of 5564 municipalities. It is essential to create more official statistics in Brazil on industrial waste, in order to understand and effectively intervene in ways that will ensure effective waste management. The official statistics in Brazil do not demonstrate the real quantitative generation and treatment of industrial waste. Map 1 shows landfills available for industrial waste disposal.

$22{ }^{21}$ Law number 6,938/81 and resolution number 420 of National Environmental Council in Brazil stipulates the values for measuring pollutants substances. See: LAW 6,938/81. Dispõe sobre a Política Nacional do Meio Ambiente, seus fins e mecanismos de formulação e aplicação, e dá outras providências. Brasília: 1981. [http://www.planalto. gov.br/ccivil_03/leis//6938.htm]. Accessed on: January 29, 2013. CONSELHO NACIONAL DO MEIO AMBIENTE. Resolution 420/09 gives guidelines on teh criteria and values for soil quality in the presence of chemical substances, and establishes directives for environmental management of areas contaminated by these substances, as a result of anthropic activities. Resoluções do Conselho Nacional do Meio Ambiente. Brasília: Ministério do Meio Ambiente, 2012.

$23{ }^{22}$ According to resolution 313/02, which illustrates the industrial solid waste inventory. ONAMA: See: CONSELHO NACIONAL DO MEIO AMBIENTE. Resolução 313/02 Dispõe sobre inventário nacional de resíduos industriais. Resoluções do Conselho Nacional do Meio Ambiente. Brasília: Ministério do Meio Ambiente, 2012. 
Map 1 - Industrial landfills in Brazil

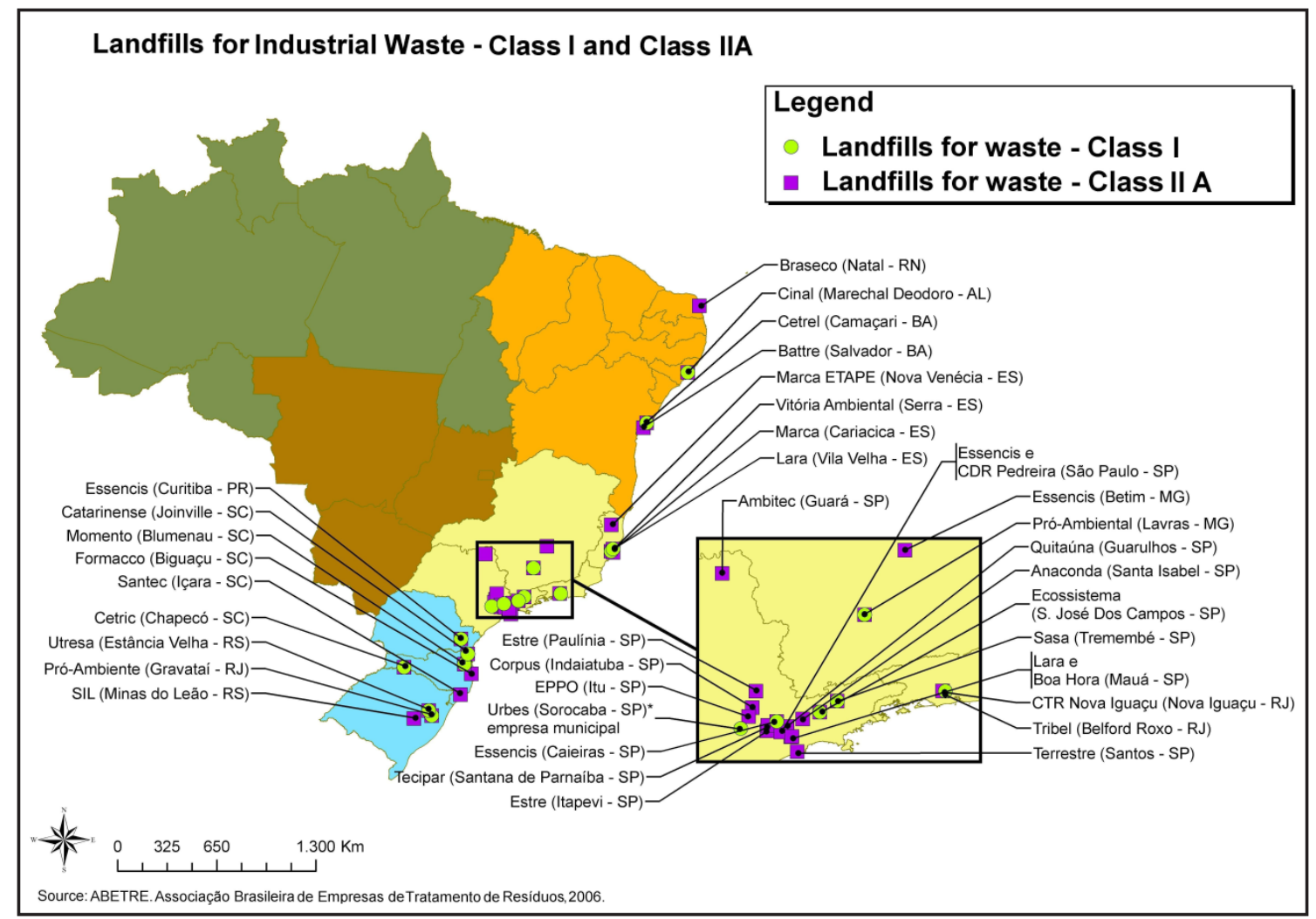

These sites for final disposal provide information that enables us to pinpoint part of the residue generated within the Brazilian territory. This information also allows Brazil to inform the Basel Convention secretariat of its industrial waste generation scenario.

Data gathering allows the Brazilian government to request financial support from the Basel Convention reserve fund, for training, control and enforcement of good management in its industries. Final industrial waste disposal and treatment technologies can use the Compensation Protocol as an instrument, foreseen in the Basel Convention, and reinforced by the working group UNEP/CHW/OEWG/6/14 (Gulis et al., 2004; Karstensen et al., 2006).

The data also reveal information on the treatment and final disposal of waste within the Brazilian territory. Having quantified this volume, industries need to treat their industrial waste, through alternative forms, such as industrial landfills, co-processing and incineration. Sometimes it is possible to reuse or recycle these wastes. Treatment practices that use incineration, co-processing, recycling and 
reuse make up only $10 \%$ of total industrial waste generation (Abetre, 2012). Another $5 \%$ is used as raw material or for energy in the manufacturing processes, a practice known as co-processing ${ }^{2423}$ (Agrawal, 2004; Babu, et al., 2007).

The main obstacles to the application of these practices in Brazil are cost, and location of the treatment sites. Incinerators and co-processing plants are mainly located Southwest region. Therefore, transporting the waste from the North and Northwest regions is impracticable, due to the enormous size of the country (see map 2). Besides the environmental risks, transport also is more expensive than disposal in landfills. There is no doubt that the above-mentioned technologies could be extensively applied by Brazilian industries, provided the operational obstacles can be properly measured.

Map 2 - Co-processing sites in Brazil

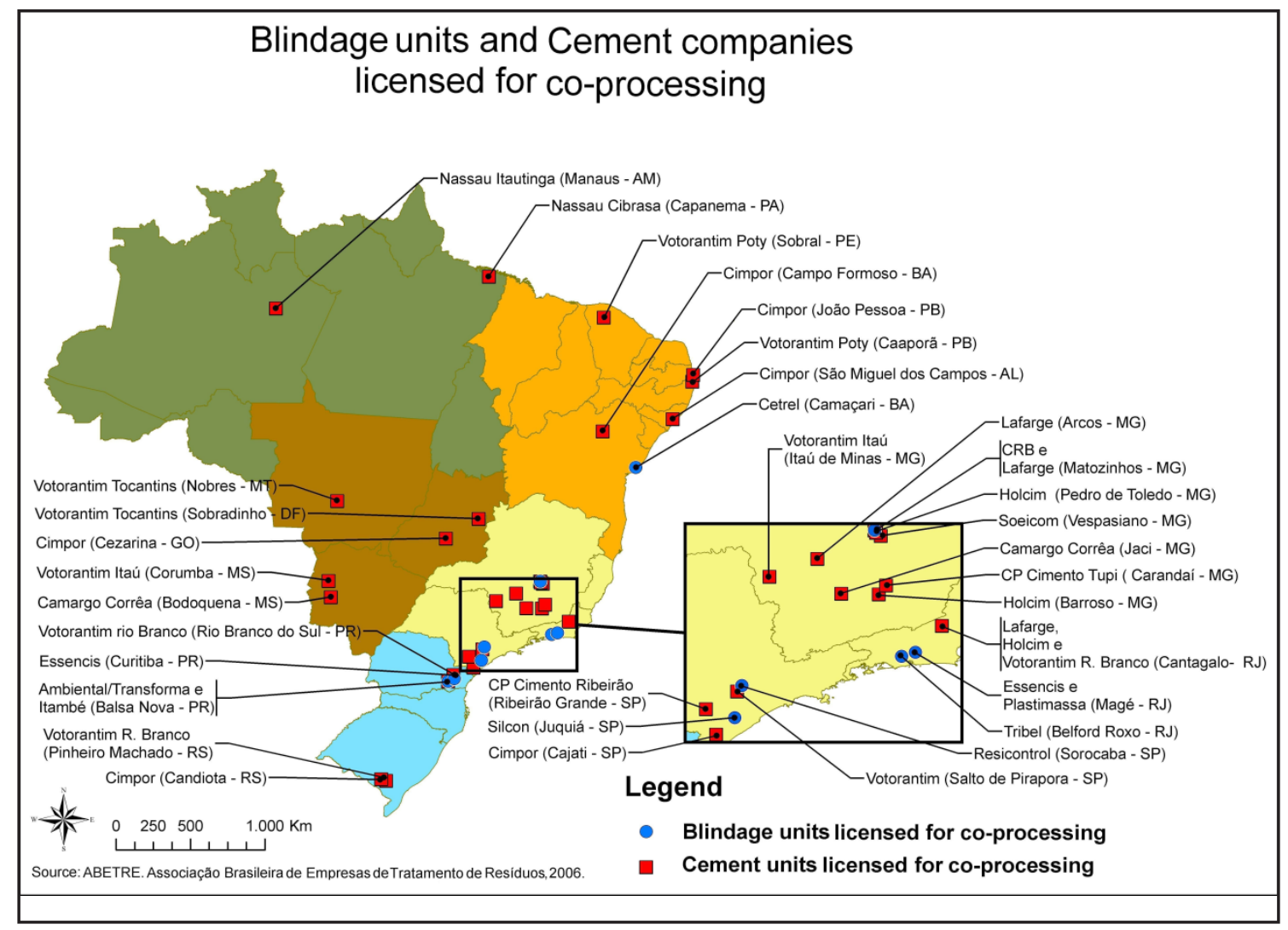

$24{ }^{23}$ Further information on practices of the Brazilian industrial sector involving clean technologies, recycling and reuse can be found at CETESB. See: COMPANHIA AMBIENTAL DO ESTADO DE SÃO PAULO. Guias de produção mais limpa para setores produtivos. São Paulo: 2010. [http://www.cetesb.sp.gov.br/tecnologia-ambiental/Produ??o-e-ConsumoSustent?vel/11-Documentos]. Accessed on: January 30, 2013. 
In terms of the Brazilian legislation on industrial solid waste, the first such law to be created was law $1,817 / 78^{2524}$, which was a result of the disaster that occurred in Cubatão in 1984, a situation that caused major environmental degradation and cost many human lives (Branco, 1984). Later, in 1988, the subject was added to the Federal Constitution ${ }^{2625}$. A lack of concern within the industrial sector, combined with delayed organization of laws in the country, lead to an absence of waste management in the industrial sector. However, when the Brazilian government signed the Basel Convention, in 1993, it became associated with an instrument that is considered important for regulating industrial waste movement in Brazil. This was the first step in reaching the goals proposed in the negotiations on movement of wastes. For this treaty to achieve success, national laws on the organization and control of waste management practices by the government are crucial.

Consolidated international policies, like the Basel Convention, gave countries the legal powers to accept or refuse the entry of industrial waste from other countries. When the Brazilian government signed the Basel Convention and incorporated it into its national legislation, it was opting to restrict waste movements that turn countries into dumping grounds for contaminated waste from other countries. But this mechanism alone is insufficient. It was also necessary to implement the Basel Convention in the legal sphere, within Brazilian institutions.

Decree 875/93 was the first reference to the Basel Convention in Brazil. It promulgates the text of the convention within the national territory, and confirms that all areas subject to Brazilian jurisdiction must comply with the convention. Brazil was one of the first signatory countries to issue a decree on the subject.

$25 \quad{ }^{24}$ Law 1.817/78. Establishes objectives and guidelines for industrial development and governs industrial zoning, localization, classification and licensing for industrial establishments in the Grande São Paulo Metropolitan Region. It is the first instrument related to this topic. See: LAW 1,817/78. Estabelece os objetivos e as diretrizes para o desenvolvimento industrial metropolitano e disciplina o zoneamento industrial, a localização, a classificação e o licenciamento de estabelecimentos industriais na Região Metropolitana da Grande São Paulo. São Paulo: 1978. [http://licenciamento.cetesb.sp.gov. br/legislacao/estadual/leis/1978_Lei_Est_1817.pdf]. Accessed on 01/29/2012.

$26{ }^{25}$ The first mention of solid waste management at national level, in Brazil, was the Brazilian Federal Constitution of 1988, article 225, 3rd paragraph, which states that activities considered damaging to the environment will incur criminal and administrative sanctions for the legal entity or individual concerned, and the obligation to repair any damages caused. See: CONSTITUIÇÃO DA REPÚBLICA FEDERATIVA DO BRASIL. Brasil: 1988. [http://www.planalto.gov.br/ccivil_03/constituicao /constitui\%C3\%A7ao.htm]. Accessed on 01/27/2013. 
Decree 5,098/04 followed, which details the National Plan for Prevention and Immediate Response to Accidents involving Hazardous Chemical Products. This instrument allows all federal units to act in the event of a transportation accident within the national territory, in order to protect the population and the environment from further damage.

The Environmental Crimes Law (9,605/98), which reinforced the abovementioned decrees, adopted the mechanisms of the 'polluter payer' principle, whereby sanctions are imposed on industrial activities that are considered potentially harmful to the environment, or production activities are restricted. This mechanism controls industrial activity, as the sanctions or restricted production imposed are in keeping with the nature of damage ${ }^{2726}$.

CONAMA Resolution 023/96 is another instrument that reinforces the Basel Convention in Brazil. It specifies the procedures for requesting authorization to transport waste to another country. CONAMA Resolution 313/02 covers the solid industrial waste inventory. These resolutions make it compulsory to issue reports of movements of waste, and no movement is possible without including a full description of the material being transported.

The ABNT standards will be the last instrument for industrial solid waste management in Brazil presented in this paper. ABNT 10,004/04 is entitled Solid Waste, and deals with waste according to its potential risks to the environment and public health.

According to this standard, hazardous waste is defined as having specific characteristics - inflammable, corrosive, reactive, toxic, pathogenic - or waste that is designated as such. Movement of hazardous waste between federal units without prior consent is prohibited. Brazil submitted this standard to the secretariat of the Basel Convention, with the intent that importing countries recognize the required characteristics within Brazilian territory. It is part of the International Standards required of Member parties by the secretariat of the

$27{ }^{26}$ The first legislation in Brazil to demonstrate the principle of "polluter-payer" was Environmental Policy Law 6,938/1981, before Brazil became a signatory of the Basel Convention. This principle emerged from the Cubatão case, in the State of São Paulo, in which many people died due to environmental pollution. The adoption of other laws reinforces the need for control and management. 
Basel Convention, in which the national inventory definition of waste must be respected in a request for waste movement, in response to decisions taken at the COP9. Topics presented in this standard will certainly be useful as inspiration for legislation in other countries.

ABNT 13.221/94 regulates waste movement and clearly defines the necessary procedures in case of accidents occurring during transportation. If the procedures are not followed, the enterprise will be answerable before the environmental bodies.

Recently, Brazil approved the National Policy for Solid Waste ${ }^{2827}$. The National Law on waste management, $12,305 / 10^{2928}$, reinforces other legal instruments that cover this topic. Articles 37 to 41 describe the rules for the generation, treatment, and final disposal of hazardous wastes. The national law reinforces the Basel Convention by obliging the industrial sector to manage its own waste. These new Brazilian rules will create more statistics and control within the country, generating information and guaranteeing control of waste movements.

From the Brazilian experience, it is important to emphasize that that the regulatory instruments created within the territory strengthen the international treaty, creating rules for Brazilian industries to search for better industrial waste management practices. A case in point is the industries in Cubatão, in the State of

$28{ }^{27}$ Argentina has law number 25.612 from 2002, titled Industrial waste Integrated Management and services activities. See: LEI 25.612/02. Regula as atividades industriais na Argentina. Buenos Aires: 2002. [http://pt.shvoong.com/law-and-politics/enviromental-law/592979-leis-res\%C3\%ADduos-industriais-argentina/]. Accessed in: 01.27.2013. Bolivia: Environmental Regulation number 1.333 from 1992 which regulates Solid Waste Management. See: GOBIERNO DE BOLÍVIA. Ley número 1333: Reglamento para actividades con sustancias peligrosas. Bogotá: 1992. [http://biblioteca.unmsm .edu.pe/ redlieds/Recursos/archivos/Legislacion/Bolivia/reglamento_sustancias.pdf]. Accessed in: 02.03.2013. Finally, Colombia under National Policy for Solid Waste from 2005. See: GOBIERNO DE COLOMBIA. Política de gestión integrada de residuos sólidos. Ministerio de medio ambiente, vivienda y desarrollo territorial. Bogotá: 2005.[http://www.presidencia.gov.co/prensa_new/decretoslinea/2005 /marzo/23/DEC838230305.pdf]. Accessed in: 02.03.2013.

$29{ }^{28}$ The Brazilian National Law about Waste, see: LEI 12.305/10. Institui a Política Nacional de Resíduos Sólidos. Brasília: 2010. [http://www.planalto.gov.br/ccivil_03/_ato20072010/2010/lei/l12305.htm]. Accessed in: 01.29.2013. Norm Instruction number 13, from 2012. INSTITUTO BRASILEIRO DO MEIO AMBIENTE E DOS RECURSOS RENOVÁVEIS. Instrução normativa para a publicação da lista brasileira de resíduos sólidos. 13, Brasília: 2012.[http://www.in.gov.br/visualiza/ind ex.jsp?data=20/12/2012\&jornal=1\&pa gina $=200 \&$ totalArquivos $=324$ ] Accessed in 01.27.2013. 
São Paulo, in the 1980s, which had no management schemes for industrial waste. That disaster that took place there exposed communities and the environment to risks. At an international level, national regulatory mechanisms demonstrate the Brazilian position of pro-cohibition of illegal hazardous waste, which is in line with the objectives of the Basel Convention. There have been many dangerous and unfortunate experiences around the world related to illegal waste movements, involving products from persistent organic pollutants to electronics. This must be avoided at all costs, as it places human lives and the environment at risk, and undermines the objectives of the Basel Convention.

\section{CONCLUSION}

Solid waste management in Brazil is a great challenge. Brazilian industries need to apply treatment technologies to avoid final disposal costs or unnecessary waste generation. The Basel Convention regulates the waste trade. However, it is the duty of the Brazilian government to enforce the process to ensure that wastes exported and imported in the Brazilian territory are, in fact, destined for use as raw material.

The meetings of the Conference of the Parties reinforced the importance of all the signatory countries imposing Transboundary waste movement control within the national territory. The Brazilian public must also be involved in ensuring the adoption of clean technologies and compliance with the legislation. Brazilian industries are regulated in relation to their waste management, under the abovementioned legislation.

Brazil will face further challenges when the Compensation Protocol comes into force. This protocol further restricts transportation of waste, and reinforces the need for strong national articulation, in order to effectively internalize the convention. Brazil has yet to sign up to this protocol. It also faces the challenge of creating laws and enforcement procedures related to its commitments under the Basel Convention.

The Brazilian experience has shown that consolidation of the Basel Convention at an international level depends on the creation of national laws associated with 
it. Moreover, inspection and official databases are indispensable as part of the process of ensuring the regulatory mechanisms are implemented.

Despite the difficulties in enforcement, transportation and final disposal of industrial waste in Brazil, and other late industrialized countries, are expected to cause less environmental impact in future. The Basel Convention aims to promote the control of hazardous waste movements and avoid transference of problems between countries. In Brazil, we can say that these conditions have been met. Nevertheless, we still have much to learn if total enforcement is to become a reality.

\section{REFERENCES TO BIBLIOGRAPHIC SOURCES CITED}

ACSELRAD, Henri. Justiça ambiental e cidadania. Rio de Janeiro: Relume Dumará, 2004.

AGRAWAL, Archana., Kanta Sahu, Kamala., Dhar Pandey, Banshi. Recenttrends a current practices for secondary processing of zinc and lead. Part I: lead recovery from secondary sources. Waste Management \& Research, 2004, 22, 240-247.

AGAMATHU, Putri. Mercury emissions: is there a global problem? .Waste Management \&Resource, 2005, 23,485-486.

ASSOCIAÇÃO BRASILEIRA DE NORMAS TÉCNICAS. Norma 10.004/04. Resíduos sólidos: classificação. São Paulo: Publicações. 2004.

ASSOCIAÇÃO BRASILEIRA DE NORMAS TÉCNICAS. Norma 13.221/94. Transporte terrestre de resíduos. Brasil: 1994 Online [http://www.ambientall.com.br/ambientall_trata/downloads/ NBR_13221_Transporte_de_residuos.pdf ]. Acesso em: 25.01.2013.

ASSOCiAÇÃO DE EMPRESAS DE TRATAMENTO DE RESíduOS. Panorama dos Resíduos Industriais. 2010.

BABU, Ramesh., Parande, Anand., Basha, Chiya. Electrical and electronic waste: a global environmental problem. Waste Management \& Research, 2007, 25, 307-31.

BARBALACE, Roberta. Environmental justice and the NIMBY principle. Environmental Chemistry. 2001. Online [http://environmentalchemistry.com/yogi/hazmat/articles/nimby. html]. Acesso em: 25.01.2013.

BASEL CONVENTION. Convenção de Basiléia sobre o controle dos movimentos transfronteiriços de resíduos perigosos e seu depósito. 1989. Online [www.basel.int]. 
Acesso em: 25.012012.

BASEL CONVENTION. Parties to the Basel Convention. 1989. Online [ http://www.basel.int/ Countries/StatusofRatifications/PartiesSignatories/tabid/1290/Default.aspx ]. Accessed on: 02/03/2013.

\section{BASEL CONVENTION. Basel Protocol on Liability and Compensation for Damage Resulting} from transboundary movements of hazardous waste. 1999. Online [www.basel.int/ratif/ protocol.htm] Acesso em: 27.01.2013

BECK, Ulrich. La sociedad del riesgo: hacia una nueva modernidad. Barcelona: Paidós, 2006.

BRANCO, Samuel. O fenômeno Cubatão na visão do ecólogo. São Paulo: CETESB, 1984.

CÓDIGO TRIBUTÁRIO NACIONAL. Fontes do direito tributário. Brasília: 1988. Online [http:// www.webjur.com.br/doutrina/Direito_Tribut_rio /Fontes_do_Direito_Tribut_rio.htm]. Accessed on: $01 / 30 / 2013$.

CONSTITUIÇÃO DA REPÚBLICA FEDERATIVA DO BRASIL. Brasil: 1988. Online[http://www. planalto.gov.br/ccivil_03/constituicao/constitui\%C3\%A7ao.htm]. Acesso em: 27.01.2013.

COMPANHIA AMBIENTAL DO ESTADO DE SÃO PAULO. Guias de produção mais limpa para setores produtivos. São Paulo: 2010. Online [http://www.cetesb.sp.gov.br/tecnologiaambiental/Produ??o-e-Consumo-Sustent?vel/11-Documentos ]. Accessed on: 01/30/2013.

CALVO GARCÍA-TORNEL, Francisco. Sociedades y territorios en riesgo. Espanha: Ediciones del Serbal, 2001.

CONSELHO NACIONAL DO MEIO AMBIENTE. Resolução 023/96 Dispõe sobre o transporte de produtos perigosos em território nacional. Resoluções do Conselho Nacional do Meio Ambiente. Brasília: Ministério do Meio Ambiente, 2012.

CONSELHO NACIONAL DO MEIO AMBIENTE. Resolução 313/02 Dispõe sobre inventário nacional de resíduos industriais. Resoluções do Conselho Nacional do Meio Ambiente. Brasília: Ministério do Meio Ambiente, 2012.

CONSELHO NACIONAL DO MEIO AMBIENTE. Resolução 420/09 Dispõe sobre critérios e valores orientadores de qualidade do solo quanto à presença de substâncias químicas e estabelece diretrizes para o gerenciamento ambiental de áreas contaminadas por essas substâncias em decorrência de atividades antrópicas. Resoluções do Conselho Nacional do Meio Ambiente. Brasília: Ministério do Meio Ambiente, 2012. 
CONSELHO NACIONAL DO MEIO AMBIENTE. O que é o CONAMA. Brasília: 2012. Online [http://www.mma.gov.br/port/conama/estr.cfm]. Accessed on: 01/30/2013.

DECRETO 5.098/04. Dispõe sobre a criação do Plano Nacional de Prevenção, preparação e resposta rápida a emergências ambientais com produtos químicos perigosos - P2R2. Brasil: 2004. Online [http://www.mp.sc.gov.br/legisla/indice/legfed_df.htm]. Accessed on: 01/27/2013.

DECRETO 875/93. Promulga o texto da Convenção sobre o Controle de Movimentos Transfronteiriços de Resíduos Perigosos e seu Depósito. Brasil: 1993. Online [https://www. planalto.gov.br/ccivil_03/decreto/D0875.htm]. Accessed on: 01/27/2013.

EL-FADELA, Mutasem. Industrial-waste management in developing countries: The case of Lebanon. Journal of Environmental Management. 2002. Online [http://dx.doi.org/10.1006/ jema.2000.0413]. Accessed on: 01/30/2013.

ELLIOTT, Lorraine. The Global Politics and Environment. United States: Macmillan 1998.

FUSEL, Masaaki., Yamasue, Eiji., Reck, Barbara. Regional development or resource preservation?: A perspective from Japanese appliance exports. Ecological Economics, 2011, 70, 788-797.

GERBER, Jean-David., Knoepfel, Peter., Nahrat, Stéphane., Varone, Frédéric. 2009. Institutional Resource Regimes: Towards sustainability through the combination of property-rights theory and policy analysis. Ecological Economics, 2009, 68, 798-809.

GOBIERNO DE COLOMBIA. Política de gestión integrada de residuos sólidos. Ministerio de medio ambiente, vivienda y desarrollo territorial. Bogotá: 2005. Online [http://www. presidencia.gov.co/prensa_new/decretoslinea/2005/marzo/23/DEC838230305.pdf].Accessed on: $02 / 03 / 2013$.

GOBIERNO DE BOLÍVIA. Ley número 1333: Reglamento para actividades con sustancias peligrosas. Bogotá: 1992. Online [ http://biblioteca.unmsm.edu.pe/redlieds/Recursos/ archivos/Legislacion/Bolivia/reglamento_sustancias.pdf ]. Accessed on: 02/03/2013.

GULIS, Gabriel., Miluba Joshua., Kosova, Beatrica., Juna Olivia. Health status of people of slums in Nairobi, Kenya. Environmental Research, 2004, 96, 2, 219-227.

INSTITUTO BRASILEIRO DE GEOGRAFIA E ESTATÍSTICA. Pesquisa Nacional de Saneamento Básico: PNSB. Online. Brasília: 2002. [www.ibge.gov.br/home/estatistica/populacao/ condicaodevida/pnsb/default.shtm]. Accessed on: 01/29/2013. 
INSTITUTO BRASILEIRO DE GEOGRAFIA E ESTATÍSTICA. Indicadores de desenvolvimento sustentável. Brasília: 2004. Online [www.ibge.gov.br/home/estatistica/populacao/ condicaodevida/pnsb/default.shtm]. Accessed on: 01/30/2013.

INSTITUTO BRASILEIRO DO MEIO AMBIENTE E DOS RECURSOS RENOVÁVEIS. Instrução normativa para a publicação da lista brasileira de resíduos sólidos. 13, Brasília: 2012. Online [http://www.in.gov.br/visualiza/index.jsp?data=20/12/2012\&jornal=1\&pagina=200\& totalArquivos=324] Accessed on: 01/27/2013.

KAMUK, Bettina., Hansen, Jens. Global recycling - waste trafficking in disguise?. Waste Management \& Research, 2007, 25, 487 - 488.

KARSTENSEN, Kare., Kinh, Nguyen., Hung Viet, Pham. (2006): Environmentally sound destruction of obsolete pesticides in developing countries using cement kilns. Environmental Science \& Policy. 2006, 9, 577-586.

KEMPEL, Willy. The negotiations on the Basel Convention on the transboundary movement of hazardous wastes and their disposal: A national delegation perspective. International Negotiation. 2004, 4, 1999, 413-434.

KRUEGER, Jonathan. Prior Informed Consent and the Basel Convention: The Hazards of What Isn't Known. The Journal of Environment \& Development.1998,7,115-137.

KUMMER, Katharina. International Management of Hazardous Wastes. Clarendon Press: Oxford 1995.

KUO-SHUH, Fan, Tien Chin Chang, Shih-Piao Ni, Ching-Hwa Lee. Transboundary hazardous waste management. Part I: waste management policy of importing countries. Waste Management \& Research. 2005, 23, 505 - 513.

LEI 25.612/02. Regula as atividades industriais na Argentina. Buenos Aires: 2002. Online [http://pt.shvoong.com/law-and-politics/enviromental-law/592979-leis-res\%C3\%ADduosindustriais-argentina/]. Accessed on: 01/27/2013.

LEI 9.605/98. Dispõe sobre as sanções penais e administrativas derivadas de condutas e atividades lesivas ao meio ambiente, e dá outras providências. Brasília: 1998. Online [ http://www.planalto.gov.br/ccivil_03/leis-/L9605.htm]. Accessed on: 01/29/2013.

LEI 1.817/78. Estabelece os objetivos e as diretrizes para o desenvolvimento industrial metropolitano e disciplina o zoneamento industrial, a localização, a classificação e o licenciamento de estabelecimentos industriais na Região Metropolitana da Grande São 
Paulo. São Paulo: 1978. Online [http://licenciamento.cetesb.sp.gov.br/legislacao/estadual/ leis/1978_Lei_Est_1817.pdf]. Accessed on: 01/29/2013.

LEI 12.305/10. Institui a Política Nacional de Resíduos Sólidos. Brasília: 2010. Online: [http://www.planalto.gov.br/ccivil_03/_ato2007-2010/2010/lei/l12305.htm]. Accessed on: 01/29/2013.

LEI 6.938/81. Dispõe sobre a Política Nacional do Meio Ambiente, seus fins e mecanismos de formulação e aplicação, e dá outras providências. Brasília: 1981. Online [http://www. planalto.gov.br/ccivil_03/leis/l6938.htm]. Accessed on: 01/29/2013.

LEFF, Enrique. Saber Ambiental: sustentabilidade, racionalidade, complexidade e poder. Rio de Janeiro: Vozes, 2001.

MÁFIA DO LIXO. Brasil na rota do tráfico internacional recebe lixo da Espanha. São Paulo: 2011. [http://www.mafiadolixo.com/2011/09/brasil-na-rota-do-trafico-internacional-recebeconteineres-carregados-com-lixo-da-espanha/]. Accessed on: 01/27/2013.

MANCINI, Sandro., Nogueira, Alex., Kagohara,Dennis. Potencial de resíduos sólidos urbanos destinados aos aterros sólidos: o caso de Indaiatuba, São Paulo, Brasil. Waste Management $\&$ Research. 2007, 25, 6,517-523.

MARTÍNEZ - ALIER, Joan. 2007. O Ecologismo dos pobres. São Paulo: Contexto, 2007.

MEYERS, Gary. Anbarci, Glen. An international waste convention: measures for achieving sustainable development. Waste Management \& Resource. 2006, 24, 505-513.

NOVEMBER, Valerie. Les Territoires du risque: le risque comme objet de refléxion géographique. Berna: Lang, 2002.

ORGANIZAÇÃO MUNDIAL DO COMÉRCIO. Waste Management Policy Group: Working Paper. Number 3, 37th Meeting, March, 1993. Online [http://ban.org/library/lipman.html\#fn2] Accessed on: 02/03/2013.

PAPU-ZAMXAKAA, Vathiswa, Harphamb, Trudy., Matheea, Angela. Environmental legislation and contamination: The gap between theory and reality in South Africa. Journal of Environmental Management. 2010, 6, 44-56. Accessed on: 01/30/2013.

PROGRAMA DAS NAÇÕES UNIDAS PARA O MEIO AMBIENTE. Global trends in generation and transboundary movements of hazardous wastes and other wastes. Suíça: Publicações, 2002. 
RIBEIRO, Wagner. A ordem ambiental internacional. São Paulo: Contexto, 2001(a).

RIBEIRO, Wagner. Desenvolvimento sustentável e segurança ambiental global. Revista Bibliográfica de Geografía y Ciencias Socialies. Barcelona: 2001b. Online [http://www. ub.edu/geocrit/b3w-312.htm ]. Accessed on: 01/30/2013.

SANCHEZ, Roberto. 2006. International Trade in Hazardous Wastes: A Global Problem with Uneven Consequences for the Third World. Waste Management \& Research. 2006, 24, 92101.

TAGGART, Mark., After the aznalcoollar mine spill: arsenic, zinc, selenium, lead and cooper levels in the livers and bones of five waterfowl species. Environmental Research. 2006. 100, 349-361.

TSIMPLIS, M. Liability and compensation in the international transport of hazardous waste by sea: the 1999 protocol to the Basel convention plus appendix transboundary movements of hazardous wastes and their disposal. Earth and Environmental Science. 2004, 11, 11.

UNITARIAN UNIVERSITY SERVICE COMMITTEE. Côte d'Ivoire Toxic Waste Dumping. 2007. Online[http://www.uusc.org/blog/2007/02/cte-divoire-toxic-waste-dumping.html]. Accessed on: 01/27/2013.

VEIGA, Marcelo. (In) Eficiência econômica e ambiental da Convenção da Basiléia. Revista de Administração. São Paulo: 2007. [http://www.revistasusp.sibi.usp.br/scielo.php?pid=S0080 21072007000200002\&script=sci_arttext ] Accessed on: 01/30/2013.

YOSHIDA, Aya., Terazono Atsushi. Reuse of secondhand TVs exported from Japan to the Philippines. Waste Management, 2010, 30, 6, 1063-1072.

YUNCHANG, Jeffrey., Yu -Lan Chien., Esher-Hsu. The market incentive recycling system for waste packaging containers in Taiwan. Environment Science \& Policy. 2004, 7, 509-523.

ZANIRATO, Silvia., RAMIRES, Jane., AMICCI, Anie., RIBEIRO, Zulimar., RIBEIRO, Wagner. Sentidos do risco: interpretações teóricas. Revista Bibliográfica de Geografía y Ciencias Socialies. Barcelona: 2008. Online [http://www.ub.edu/geocrit/b3w-785.htm]. Accessed on: 01/30/2013. 